\title{
BILI SKELI LIMESTONE CLIFFS AS AN IMPORTANT HOTSPOT OF PLANT DIVERSITY IN THE CHYVCHYNY MOUNTAINS (UKRAINIAN CARPATHIANS)
}

\author{
Yuriy KOBIV $V^{1,2}$, Andriy PROKOPIV ${ }^{2}$ \\ ${ }^{1}$ Institute of Ecology of the Carpathians, National Academy of Sciences of Ukraine, \\ 4 Kozelnytska Str., 79026 Lviv, Ukraine \\ ${ }^{2}$ Botanical Garden of Ivan Franko National University of Lviv, 44 Cheremshyny Str., 79014 Lviv, Ukraine \\ e-mail: ykobiv@gmail.com
}

\begin{abstract}
In this paper we present the flora of Bili Skeli (White Cliffs) Massif. This site is the southernmost group of limestone cliffs in the Ukrainian Carpathians, situated in the montane forest belt in the headwaters of the Bilyi Cheremosh River (Verkhovynskyi National Nature Park, the Chyvchyny Mts.). These cliffs harbour rare calcareous saxicolous species, e.g. Arabis hornungiana, Carduus defloratus subsp. glaucus, Cystopteris alpina, Epipactis atrorubens, E. helleborine, Goodyera repens, Saussurea discolor, Saxifraga luteoviridis and Thymus pulcherrimus, many of them included in the Red Data Book of Ukraine (2009). Their occurrence was analysed in their ecological and conservation context. A map of the site is provided as well as geographical coordinates of the major cliffs. The occurrence of obligatory calcicole rare species is determined by the limestone bedrock, which is infrequent in the Ukrainian Carpathians. The rarity of the habitat type makes the site one of the few disjunct environmental islands of calcareous flora in the region. Some of the listed species are narrow-range and occur at the edge of their geographical distribution. Moreover, Saussurea discolor is confined to the lowermost limit of its altitudinal range. Such marginality makes the area remarkable in biogeographical and conservation terms. It was revealed that a population of another rare species, Saxifraga aizoides, has possibly become extinct at this site. However, the confirmed occurrence of Saussurea discolor makes the Bili Skeli cliffs the second (in addition to Chonyi Dil Mt.) known locality of that species in the Ukrainian Carpathians.
\end{abstract}

Keywords: rare species, distribution, calcareous species, endemic plants

\section{Introduction}

Rare plant species of the Ukrainian Carpathians are mostly stenotopic and their populations are confined to special types of habitats that are infrequent in the region. One such habitat type is limestone cliffs and outcrops, which harbour calcicole species. Alkaline calcareous bedrock is very rare in the Ukrainian Carpathians that are mainly constituted of acidic sandstone flysch [19]. Therefore, scarce Triassic-Jurassic limestone makes disjunct environmental islands that occur mostly in the Chyvchyny Mts. and also stretch throughout the Transcarpathian (Zakarpattya) Region along the boundary between the Inner and Outer Carpathians forming a chain of cliffs called the Marmarosh and Pieniny Klippen Belt [13, 15]. They are very interesting in biogeographical terms because they provided a stepping-stone for the dispersal routes of some calcareous mountain species along the Carpathians in the past [26].

The largest and best known limestone cliffs in the Chyvchyny Mts. are Velykyi Kamin' (on the Chornyi Dil Range) and Mokryniv Kamin', which reach over $1400 \mathrm{~m}$ a.s.l. and harbour many rare calcicolous taxa, including Achillea oxyloba subsp. schurii, Aconitum anthora, 
Aquilegia nigricans, Carduus defloratus subsp. glaucus, Crepis jacquinii, Erysimum witmannii subsp. transsilvanicum, Leontopodium alpinum, Saussurea discolor and Silene zawadzkii. These remarkable habitats have been thoroughly surveyed and described by a number of authors $[3,4$, $24,27]$. Other localities of rare calcicole species have also been discovered recently on the limestone outcrops in the headwaters of the Bilyi Cheremosh River in the Chyvchyny Mts., particularly in the Preluchnyi Stream valley [5] and on the Zhupany Range [6].

This article describes another hotspot of the calcicole flora in the Chyvchyny Mts - a set of limestone cliffs at the foot of Hnetesa and Palenytsia Mts. called Bili Skeli (White Cliffs). Some data on the occurrence of certain rare species in that area were published by Pawłowski and Walas (1949), Milkina (1994), Velychko and Chorney (2004) but they do not fully reflect the conservation value of the site. The aim of this study is to describe the floristic composition of the site, determine the status of populations of rare and endangered species and show the exact location of their habitats.

\section{Material and Methods}

The results presented below were obtained during field research carried out in July 2012 in the Chyvchyny Mts, Ukrainian Carpathians. Geological maps of the region [13, 25] have been used to reveal the limestone outcrops. The phytosociological relevés and the schemes of their localization given in Pawłowski and Walas's publication (1949) have been analysed to assess the changes in the species' distribution. In addition, corresponding herbarium material from the Chyvchyny Mts has been checked, particularly the personal collections of Mądalski and Pawłowski from the Herbarium of W. Szafer Institute of Botany, Polish Academy of Sciences, Kraków (KRAM), as well as the main Ukrainian herbaria which contain Carpathian specimens (LW, LWS, KW, CHER, UU, LWKS).

The density of populations was estimated based on square plots placed randomly using $0.5 \times 0.5 \mathrm{~m}$ frames with 10 -fold repetition [11].

Species abundance is presented according to the Braun-Blanquet scale [2].

Considerations on species endemism are based on Kliment et al. (2016).

The content of calcium and magnesium in soil was assessed by complexometric titration with the aid of metallochromic indicators, and the $\mathrm{pH}\left(\mathrm{H}_{2} \mathrm{O}\right)$ value by potentiometric measurement using standard hydrogen electrode [1].

Nomenclature for vascular plants follows Mirek et al. (2002) with modern updates for endemics by Kliment et al. (2016), Hill et al. (2006) for bryophytes, and Malynovski and Kricsfalusy (2002) for phytosociological units.

The collected specimens of rare species are deposited at the Herbarium of Ivan Franko National University of Lviv (LW).

\section{Results}

Bili Skeli is the southernmost group of limestone cliffs in the Ukrainian Carpathians. They are situated in the montane forest belt in the headwaters of the Bilyi Cheremosh River within 1280-1400 m a.s.l. The limestone cliffs studied are scattered along the left banks of two streams that flow down from Mt. Hnetesa and Mt. Palenytsia and form the Minchel Stream (Fig. 1). Further downstream it merges into the Perkalab Stream, the largest watercourse tributary of the Bilyi Cheremosh River. 
There are 6 major limestone cliffs (10-30 m high), 3 on each of the two streams (Fig. 1). Their geographic coordinates and elevation are: locality $1-47^{\circ} 44^{\prime} 11.9^{\prime \prime} \mathrm{N}, 24^{\circ} 54^{\prime} 07.1^{\prime \prime} \mathrm{E}, 1290 \mathrm{~m}$ a.s.1.; $1-47^{\circ} 66^{\prime} 11.9^{\prime \prime} \mathrm{N}, 2^{\circ} 64^{\prime} 07,1^{\prime \prime E}, 1290 \mathrm{~m}$ a.s.1.; $2-47^{\circ} 44^{\prime} 19.7^{\prime \prime} \mathrm{N}, 24^{\circ} 54^{\prime} 11.9^{\prime \prime} \mathrm{E}, 1380 \mathrm{~m}$ a.s.1.; $3-47^{\circ} 44^{\prime} 21.7^{\prime \prime} \mathrm{N}, 24^{\circ} 54^{\prime} 00.4^{\prime \prime E}, 1390 \mathrm{~m}$ a.s.1.; $4-47^{\circ} 44^{\prime} 20.7^{\prime \prime} \mathrm{N}, 24^{\circ} 54^{\prime} 26.1^{\prime \prime} \mathrm{E}, 1330 \mathrm{~m}$

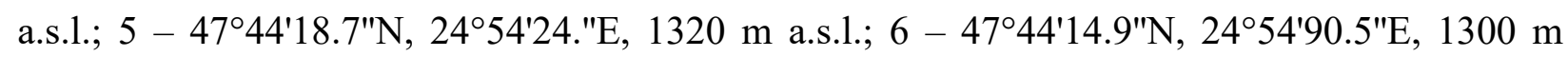
a.s.1. (numbers of localities correspond to those in Figure 1). There is also a set of smaller limestone cliffs and outcrops in the vicinity of these localities.

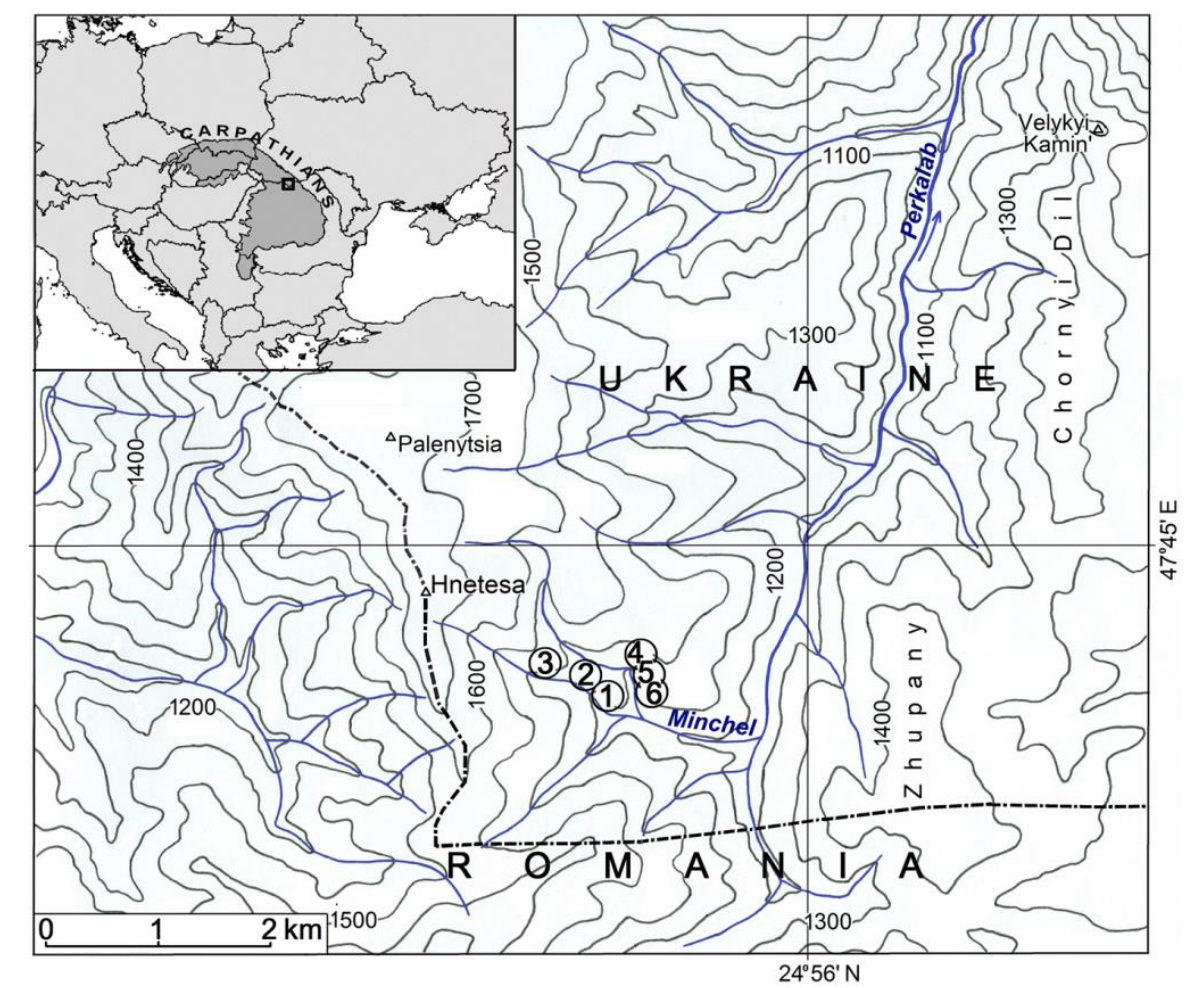

Fig. 1: Location of the Bili Skeli limestone cliffs in the Chyvchyny Mts, Ukrainian Carpathians; $1,2 \ldots 6$ - locality numbers (for details, see the Results).

The cliff with the lowest altitude located at the upper stream (locality 1), is the most interesting concerning its flora. It is about $15 \mathrm{~m}$ high and its steep (ca $70^{\circ}$ ) SW slope faces the stream. Vegetation cover at the site is about $50 \%$ and is formed by the following species with corresponding grades of abundance: Saussurea discolor - 1, Saxifraga luteoviridis - +, Trisetum alpestre -1 , Arabis hornungiana -+ , Asplenium ruta-muraria -+ , A. viride -1 , Atragene alpina -+ , Calamagrostis arundinacea -1 , Carex ornithopoda -+ , Cirsium erisithales -+ , Cruciata glabra -+ , Cystopteris alpina -+ , C. fragilis -+ , Festuca carpatica -3 , Galium anisophyllon -+ , Hieracium bifidum -+ , Phyteuma orbiculare -1 , Picea abies -1 , Polystichum aculeatum -+ , Thymus pulcherrimus -+ , Veronica urticifolia -1 , Viola biflora,-+ Ctenidium molluscum - 3, Fissidens dubius - 2, Mnium thomsonii - 1, Tortella tortuosa - 3 .

This locality was first discovered in the 1930s by Pawłowski and Mądalski, confirmed by numerous herbarium sheets gathered by these two botanists. It is marked on the map in Pawłowski and Walas's (1948) publication about the vegetation of the Chyvchyny Mts, which also contains a brief phytosociological relevé of the site. The species composition in the relevé, the mark on the map and the site descriptions from the herbarium labels show that they refer to the same cliff. In addition to the species listed above, two herbarium sheets collected by 
Mądalski in 1935 and 1936 (KRAM 48673-74) prove that another rare species (Saxifraga aizoides) also occurred at that locality. However, we were not able to reconfirm the presence of the species at this locality [16].

The occurrence of Saussurea discolor, known from the Alps, Carpathians, Apennines and Rila Mts [20], is chorologically most interesting (Fig. 2). Despite the fact the species was documented in that locality in 1935 by Madalski's find (KRAM 304499), it has remained unnoticed in the Ukrainian conservation and floristic literature which considers Mt. Chornyi Dil the only species locality in Ukraine $[3,8]$. On the cliff described above, $S$. discolor occurs over c. $50 \mathrm{~m}^{2}$. The survey revealed 12 flowering and 200-250 vegetative individuals.

The middle cliff on the upper stream (locality 2) is the highest within the Bili Skeli massif, i.e. about $40 \mathrm{~m}$ tall (Fig. 3). It harbours a large population of Saxifraga luteoviridis.

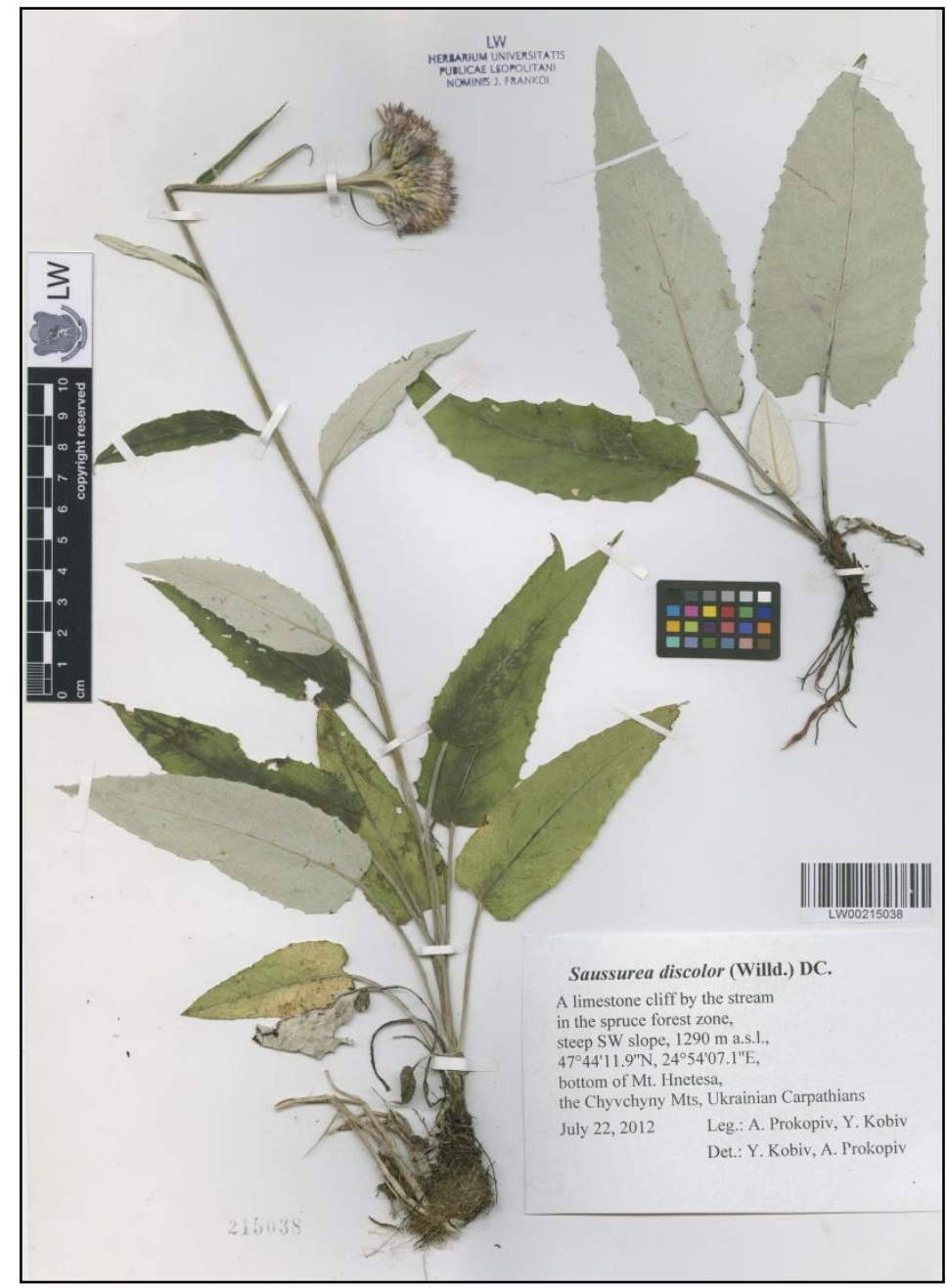

Fig. 2: A voucher herbarium specimen of Saussurea discolor from the Bili Skeli locality

The uppermost cliff (locality 3) is remarkable as a habitat of three orchid species rare in Ukraine: Goodyera repens, Epipactis atrorubens, and E. helleborine. The latter two species are most abundant on a scree at the bottom of the cliff where their density reaches up to 10 flowering individuals per $\mathrm{m}^{2}$.

The other three localities (no. 4, 5, 6) along the lower stream are situated close to each other. The lower parts of the cliffs, especially their south-eastern aspects, are very interesting, 
with Saxifraga luteoviridis and Carduus defloratus subsp. glaucus occuring there. The density of the first species may reach up to $20-25$ inds $/ \mathrm{m}^{2}$, while for the second one it is 3-4 flowering individuals per $\mathrm{m}^{2}$. The species composition is similar in all the three localities by the lower stream. In the locality 6 we identified: Saxifraga luteoviridis - 1, Trisetum alpestre - +, Aconitum degenii - +, Hieracium bifidum - +, Asplenium ruta-muraria - +, Atragene alpina - +, Carduus defloratus subsp. glaucus -1 , Cirsium erisithales,-+ C. oleraceum,-+ Cruciata glabra - +, Cystopteris fragilis - +, Festuca carpatica -1, F. rubra L. - +, Fragaria vesca -+ , Galium schultesii - 1, Phyteuma orbiculare - +, Picea abies - 2, Polygonatum verticillatum - +, Salix silesiaca - 2, Scabiosa lucida subsp. barbata - +, Silene nutans subsp. dubia -+, Sorbus aucuparia - 2, Spiraea chamaedryfolia - 1, Thymus alpestris - +, Veronica urticifolia - 1, Abietinella abietina - 2, Rhytidium rugosum - 2 .

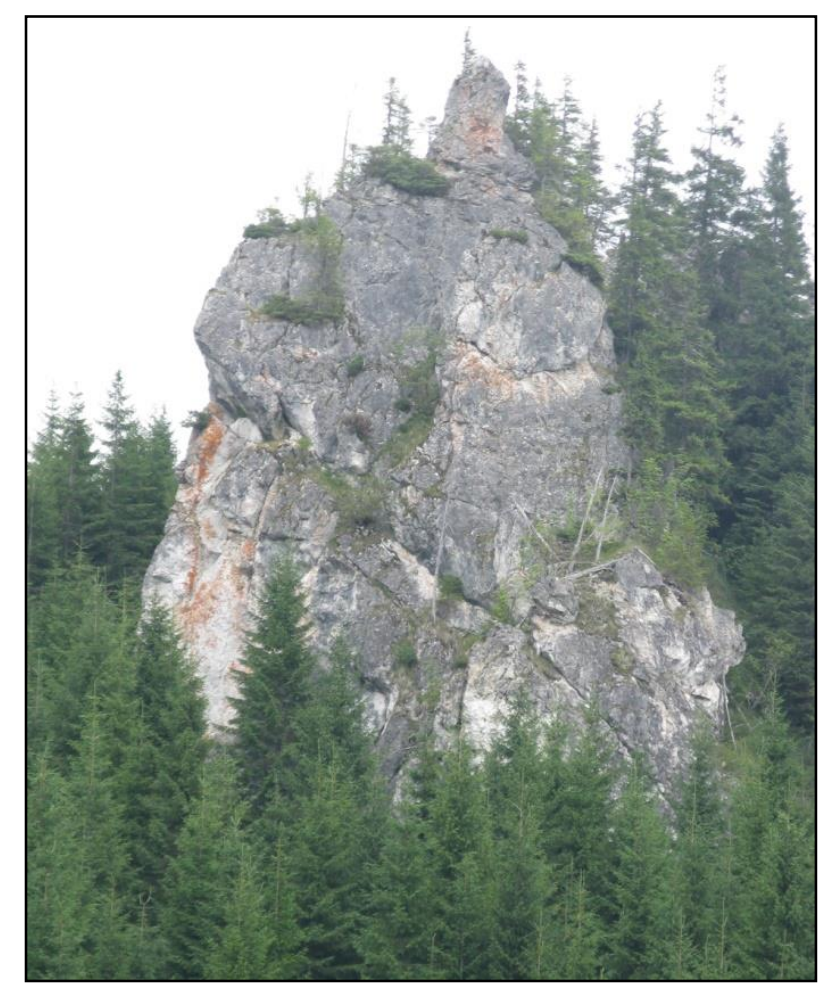

Fig. 3: The highest limestone cliff in the Bili Skeli massif (locality 2 in the text)

According to Pawłowski and Walas (1949), such calcareous saxicolous communities belong to the Saxifragetum luteoviridis association (Cystopteridion alliance), which is very rare in Ukraine and occurs only in the Chyvchyny Mts. This association is considered endemic to the Eastern Carpathians [21].

The $\mathrm{pH}\left(\mathrm{H}_{2} \mathrm{O}\right)$ value ranges within 6.71-7.39 interval, while the content of calcium is 28.2-41.5 mg-equivalents and magnesium 11.3-17.2 mg-equivalents per $100 \mathrm{~g}$ of soil.

\section{Discussion}

The Bili Skeli cliffs are remarkable for their floristic diversity. Firstly, they harbour such rare stenotopic species as: Arabis hornungiana (Carpathian-Balcan distribution), Carduus defloratus subsp. glaucus (Alpine-Carpathian subendemic), Saxifraga luteoviridis (East-SouthApuseni-Carpathian-Balkan-Anatolian distribution), Thymus pulcherrimus (West-East-South- 
Carpathian subendemic). They occur only in a few localities in Ukraine. For example, in the Ukrainian Carpathians Saxifraga luteoviridis is known only from several localities all situated on the limestone bedrock in the Chyvchyny Mts [28]. Scabiosa lucida subsp. barbata and Silene nutans subsp. dubia (East-South-Apuseni-Carpathian endemics), Aconitum degenii (panCarpathian endemic), and Festuca carpatica (West-East-South-Carpathian endemic) also occur at the site, however they are much more frequent in the region.

It is noteworthy that the rarest for the Ukrainian Carpathians of the obligatory calcicole species occur in the Bili Skeli massif at the northern or north-eastern edge of their geographical ranges (e.g. Arabis hornungiana, Carduus defloratus subsp. glaucus, Saxifraga luteoviridis, Saussurea discolor) or their Central European part (Cystopteris alpina).

Some of these species are not only geographically peripheral, but also ecologically marginal, i.e. occur at atypically low elevations. For instance, Saussurea discolor, regarded in the mountains of Central Europe as primarily a high-mountain species [9], is confined to the montane forest belt on the Bili Skeli cliffs. This also applies to Saxifraga aizoides [16, 29] of which the possible extinction at the site is in line with the decline of the other high-mountain species at the lower limit of their distribution in the Ukrainian Carpathians [17, 18]. The Bili Skeli cliffs are also the lowermost habitat of Saxifraga aizoides in Ukraine [28]. Many of the species listed above are included in the Red Data Book of Ukraine (2009) [8].

The cliffs described are situated in the Verkhovynskyi National Nature Park which was founded in 2010. Therefore, almost no anthropogenic activity has been carried out there lately. However, in 2007-2008 localities no. 1, 4, 5, 6 underwent intensive logging, which resulted in higher insolation in the herb layer. Apparently, it was favourable for heliophytous rare species, e.g. Arabis hornungiana, Carduus defloratus subsp. glaucus, Thymus pulcherrimus, Saussurea discolor, Saxifraga luteoviridis, which demonstrate the highest abundance in the open niches. Therefore, further reforestation may have an adverse effect on them, as was described recently for other large limestone cliffs in the Chyvchyny Mts. Thus, thinning of the tree and shrub layers was recommended to stop the decline of rare saxicolous light-demanding herbaceous species [7].

\section{Conclusions}

The Bili Skeli cliffs are an important hotspot of phytodiversity in biogeographical terms. The southernmost limestone rock massif in the Ukrainian Carpathians, they harbour populations of rare mountain calcareous saxicolous species. Some of these may have a unique gene pool, because they are geographically and ecologically marginal [10].

Acknowledgements: We are grateful to Dr. I. Danylkiv, Ivan Franko National University of Lviv, for determining the bryophytes. The research was supported by the Ministry of Education and Science of Ukraine (grant no. 112U001296).

\section{REFERENCES}

1. Arinushkina, E.V., 1970, Manual on soil chemical analysis, Izdatelstvo Moskovskogo Universiteta, Moscow, [in Russian].

2. Braun-Blanquet, J., 1964, Pflanzensoziologie, Grundzüge der Vegetationskunde, 3rd ed., Springer, Wien-New York. 
3. Chopyk, V.I., 1976, High-mountain flora of the Ukrainian Carpathians, Naukova Dumka, Kyiv, [in Ukrainian].

4. Chorney, I.I., Skilskyi, I.V., Korzhyk, V.P., Budzhak, V.V., 2001, Protected areas of national importance of the Bukovina as the base of regional ecological network, Zapovidna Sprava v Ukrayini, 7(2): 73-98, [in Ukrainian].

5. Chorney, I.I., Budzhak, V.V., 2003, New locality of rare species in the Chyvchyny Mountains (Ukrainian Carpathians), Ukrainian Botanical Journal, 60(1): 53-57, [in Ukrainian].

6. Chorney, I.I., Budzhak, V.V., Velychko, M.V., 2004, Botanical characteristics of the Zhupany Natural Landmark of local importance (Bukovina Carpathians). In: Materials of the International Scientific Conference devoted to the $150^{\text {th }}$ anniversary of the Botanical Garden of I. Franko National University of Lviv: 120, [in Ukrainian].

7. Chorney, I.I., Bantyshev, A.F., Velychko, M.V., Skilskyi I.V., (eds), 2018, Ecological management of territory, conservation of landscape and biotic diversity, recreation resources and perspectives of development of the Cheremosh National Nature Park. Druk Art, Chernivtsi, [in Ukrainian].

8. Didukh, Ya.P., (ed.), 2009, Red data book of Ukraine. Plant kingdom, Globalconsulting, Kyiv, [in Ukrainian].

9. Ellenberg, H., Weber, H.E., Düll, R., Wirth, V., Werner, W., Paulissen, D., 1992, Zeigerwerte von Pflanzen in Mitteleuropa, Scripta Geobotanica, 18: 1-258.

10. Hampe, A., Petit, R.J., 2005, Conserving biodiversity under climate change: the rear edge matters, Ecology Letters, 8: 461-467.

11.Harper, J.L., 1997, Population biology of plants, Academic Press, New York-London-San Francisco.

12. Hill, M.O., Bell, N., Bruggeman-Nannenga, M.A., Brugués, M., Cano, M.J., Enroth, M.J., Flatberg, K.I., Frahm, J.-P., Gallego, M.T., Garilleti, R., Guerra, J., Hedenäs, L., Holyoak, D.T., Hyvönen, J., Ignatov, M.S., Lara, F., Mazimpaka, V., Muñoz, J., Söderström, L., 2006, An annotated checklist of the mosses of Europe and Macaronesia, Journal of Bryology, 28(3): 198-267.

13. Jankowski, L., Kopciowski, R., Ryłko, W., (eds), 2007, Geological map of the Outer Carpathians: borderland of Ukraine and Romania, Polish Geological Instititute, Warsaw.

14. Kliment, J., Turis, P., Janišová, M., 2016, Taxa of vascular plants endemic to the Carpathian Mts., Preslia, 88: $19-76$.

15. Kobiv, Y., 2010, Ecological characteristics of habitats of rare plant species in the Ukrainian Carpathians, Ukrainian Botanical Journal, 67(3): 355-372, [in Ukrainian].

16. Kobiv, Y., 2016, Saxifraga aizoides (Saxifragaceae) in Ukraine, Polish Botanical Journal, 61(1): 65-71.

17. Kobiv, Y., 2017, Response of rare alpine plant species to climate change in the Ukrainian Carpathians, Folia Geobotanica, 52(2): 217-226.

18. Kobiv, Y., 2018, Trends in population size of rare plant species in the alpine habitats of the Ukrainian Carpathians under climate change, Diversity, 10(3): 1-12.

19. Kondracki, J., 1989, Karpaty, Wydawnictwo Szkolne i Pedagogiczne, Warszawa.

20. Lipschitz, S.J., 1976, Saussurea DC. In: Tutin, T.G., Heywood, V.H., Burges, N.A., Moore, D.M., Valentine, D.H., Walters, S.M., Webb, D.A., (eds.), Flora Europaea (4), Cambridge University Press, Cambridge-NewYork-Melbourne: 216-217.

21. Malynovski, K., Kricsfalusy, V., 2002, Plant Communities of the Ukrainian Carpathian Highlands, Karpatska Vezha, Uzhgorod, [in Ukrainian].

22. Milkina, L.I., 1994, New locality of Saxifraga luteo-viridis Schott et Kotschy (Saxifragaceae) in the Ukrainian Carpathians, Ukrainian Botanical Journal, 51(6): 137-140, [in Ukrainian].

23. Mirek, Z., Piękoś-Mirkowa, H., Zając, A., Zając, M., 2002, Flowering plants and pteridophytes of Poland. A Checklist, W. Szafer Institute of Botany, Polish Academy of Sciences, Kraków.

24. Pawłowski, B., Walas, J., 1949, Les associations des plantes vasculaires des Monts de Czywczyn, Bulletin International de l'Académie Polonaise des Sciences et des Lettres, Serie B, 1: 117-181.

25. Pazdro, Z., 1934, Mapa geologiczna Gór Czywczyńskich, Atlas, Lwów.

26. Sramkó, G., 2004, "Dunántúli” közép-dunai flóraválasztós fajok a Matricum flórájában, Kitaibelia, 9(1): 3156.

27. Velychko, M.V., Chorney, I.I., 2003, Botanical characteristics of the area of Mokryniv Kamin' in the Chyvchyny Mountains (Ukrainian Carpathians), Zapovidna Sprava v Ukrayini, 9(2): 16-18, [in Ukrainian]. 
28. Velychko, M.V., Chorney, I.I., 2004, On the distribution of Saxifraga luteo-viridis Schott. et Kotschy (Saxifragaceae) in the Ukrainian Carpathians. In: Materials of the International Scientific Conference devoted to the $150^{\text {th }}$ anniversary of the Botanical Garden of I. Franko National University of Lviv: 92-94, [in Ukrainian].

29. Webb, D.A., Gornall, R.J., 1989, Saxifrages of Europe, Christopher Helm, London.

\section{MASIVELE CALCAROASE BILI SKELI - UN IMPORTANT CENTRU DE DIVERSITATE FLORISTICĂ DIN MUNNȚII CHYVCHYNY (CARPAȚII UCRANIENI)}

\section{(Rezumat)}

În această lucrare prezentăm flora masivelor Bili Skeli (White Cliffs). Zona de studiu reprezintă o parte din grupul calcaros cel mai sudic al Carpaţilor ucrainieni, situat în etajul montan de la izvoarele râului Bilyi Cheremosch. Au fost identificate o serie de specii saxicole calcaroase rare, ca de ex. Arabis hornungiana, Carduus defloratus subsp. glaucus, Cystopteris alpina, Epipactis atrorubens, E. helleborine, Goodyera repens, Saussurea discolor, Saxifraga luteoviridis şi Thymus pulcherrimus, multe dintre ele fiind incluse in Cartea roşie a Ucrainei din 2009. Prezenţa lor a fost analizată în context ecologic şi conservativ. O hartă a poziţiei terenului este realizată pe baza coordonatelor geografice a rocilor importante. Prezența speciilor calcicole rare este determinată obligatoriu de rocile calcaroase care nu sunt frecvent întâlnite în Carpaţii Ucrinieini. Raritatea tipului de habitat face ca acesta să fie unul dintre puţinele insule disjuncte de flora calcaroasă în regiune. Unele specii au o răspândire restrânsă şi apar la marginea distribuţiei lor geografice. În plus, Saussurea discolor atinge aici limita inferioară a distribuției sale altitudinale, ceea ce face zona remarcabilă din punct de vedere. biogeografic şi conservativ. Este posibil ca populaţia unei alte specii rare - Saxifraga aizoides - să fi dispărut din acest site. Prezenta speciei Saussurea discolor face ca masivele Bilyi Skeli să reprezinte a doua locaţie cunoscută a acestei specii în Carpaţii ucrainieni. 